\title{
НОВОЕ ПОКОЛЕНИЕ ПЕПТИДОМИМЕТИКОВ НА ОСНОВЕ ВОДОРАСТВОРИМЫХ ПИЛЛАР[5]АРЕНОВ
}

\author{
А.А. Назарова, И.И. Стойков \\ Химический институт им. А. М. Бутлерова, Казанский федеральный университет, \\ 420008, Россия, Казань, Кремлёвская, 18.
}

DOI: 10.19163/MedChemRussia2021-2021-263

E-mail: anas7tasia@gmail.com

Молекулярное распознавание в воде является основой для различных жизненно важных процессов. На сегодняшний день синтезировано значительное количество макроциклических соединений (циклодекстрины, кукурбитурилы, каликсарены и их тиа-аналоги), которые способны связывать молекулы «гостей» в воде. Пилларарены являются новым типом синтетических «хозяев» с превосходной способностью к молекулярному распознаванию. Данный класс макроциклических соединений играет особую роль в современных исследованиях ввиду того, что представляет собой строительные блоки, используемые для создания супрамолекулярных полимеров и сенсоров, чувствительных к большому количеству субстратов различного типа. Так, введение хиральных аминокислотных фрагментов в структуру пиллар[5]арена позволит создавать на их основе водорастворимые рецепторы, а также использовать их для доставки лекарственных средств и применять в качестве ионных каналов.

В ходе проведённого исследования был синтезирован ряд новых водорастворимых пиллар[5]аренов, содержащих аминокислотные фрагменты. Структура полученных соединений подтверждена комплексом физических методов (ЯМР ${ }^{1} \mathrm{H},{ }^{13} \mathrm{C}$, ИК спектроскопия, масс-спектрометрия, а состав - элементным анализом). Изучены комплексообразующие свойства синтезированных макроциклов по отношению к некоторым хиральным и нехиральным гостям, содержащим сульфогруппу. Показано применение S-камфорсульфоновой кислоты (S-CSA) в качестве хирального темплата для пиллар[5]арена, содержащего фрагменты L-Ala, вокруг которого происходит сборка нового типа структур.

Исследование выполнено при финансовой поддержке РНФ (грант № 17-13-01208) и грантов Президента Российской Федерации для государственной поддержки молодых российских ученых - кандидатов наук (МК-723.2021.1.3) и ведущих научных школ Российской Федерации (НШ-2499.2020.3). 